\title{
How reliable are G-protein-coupled receptor antibodies?
}

\author{
Martin C. Michel • Thomas Wieland • Gozoh Tsujimoto
}

Received: 7 January 2009 / Accepted: 7 January 2009 / Published online: 27 January 2009

(C) The Author(s) 2009. This article is published with open access at Springerlink.com

\begin{abstract}
A cluster of manuscripts in this issue of the Journal highlights a lack of selectivity of 49 antibodies against 19 subtypes of $\alpha_{1}$ - and $\beta$-adrenoceptors, muscarinic, dopamine and galanin receptors as well as vanilloid (TRPV1) receptors. Taken together these data demonstrate that lack of selectivity appears to be the rule rather than the exception for antibodies against G-protein-coupled and perhaps also other receptors. Thus, the previously often applied validation of such antibodies by the disappearance of staining in the presence of blocking peptide, i.e. the antigen against which the antibody was raised, alone is insufficient to demonstrate specificity. We propose that receptor antibodies should be validated by at least one of the following techniques: a) disappearance of staining in knock-out animals of the target receptor, b) reduction of staining upon knock-down approaches such as siRNA treatment, c) selectivity of staining in immunoblots or immunocytochemistry for the target receptor vs. related subtypes when expressed in the same cell line and/or d) antibodies raised against multiple distinct epitopes of a receptor yielding very similar staining patterns. Other issues
\end{abstract}

\footnotetext{
M. C. Michel $(\bowtie)$

Department Pharmacology \& Pharmacotherapy,

Academic Medical Center,

Meibergdreef 15,

1105 AZ, Amsterdam, The Netherlands

e-mail: m.c.michel@amc.nl

T. Wieland

Department Experimental and Clinical Pharmacology,

Mannheim Medical Faculty, University of Heidelberg,

Heidelberg, Germany

G. Tsujimoto

Department Genomic Drug Discovery Science, Graduate School of Pharmaceutical Sciences, Kyoto University, Kyoto, Japan
}

of consideration to obtain reliable results based on receptor antibodies in applications such as immunohistochemistry or immunoblotting are also being discussed.

Keywords G-protein-coupled receptor · Antibody · Adrenoceptor $\cdot$ Muscarinic receptor - Dopamine receptor . Galanin receptor Vanilloid receptor

G-protein-coupled receptors (GPCR) are important regulators of cellular function (Penn 2008). They can be subdivided into classes, families and individual subtypes. Assigning specific functions to a given GPCR often requires determining which subtype is expressed in a specific cell. As GPCR mRNA and protein expression at the cell surface do not necessarily correlate, detection at the protein level is frequently required. GPCR protein detection may also be helpful to identify which cell type within a tissue expresses a given receptor and/or in which subcellular component receptors are found. Moreover, the expression density of GPCR at the cell surface is not a static entity but rather dynamically regulated by a variety of physiological and pathophysiological conditions as well as drug treatment (Insel et al. 2007). A better understanding of such regulation also often requires specific quantification of expression at the protein level. While genetically modified, e.g. HA- or His-tagged receptors, can easily be detected using antibodies against the respective tag (Jongsma et al. 2007), such detection is not applicable to endogenous receptors. Hence, the detection of native GPCR protein typically relies on the use of either specific radioligands, otherwise labelled ligands or antibodies. While radioligands have been extremely useful for studies of many GPCR (Myslivecek et al. 2008; Myslivecek et al. 2007) and continue to emerge, e.g. for nociceptin/orphanin FQ receptors (Ibba et al. 2008), suitable radioligands are missing for many other GPCR, e.g. for $\beta_{3}$-adrenoceptors 
(Vrydag and Michel 2007) or free fatty acid receptors (Tanaka et al. 2008). Therefore, antibodies are the only available option to detect many GPCR, and numerous such antibodies are commercially available from various suppliers. If these would be reliable, they would be highly important tools for pharmacological studies. Technical approaches for the generation and validation of receptor antibodies have been reviewed comprehensively (Gupta and Devi 2006; Mackrill 2004).

Doubts about the usefulness of antibodies against GPCR (O'Connell et al. 2006; Pradidarcheep et al. 2008; Rhodes and Trimmer 2006), receptors from the ligand-gated ion channel family (Herber et al. 2004) or transmitter transporters (Chen et al. 2004) have been raised in the past and have even led to the retraction of papers (Hawes and Picciotto 2005). However, these reports have largely been thought to represent isolated cases and did not raise more fundamental questions about the use of receptor antibodies. Hence, receptor antibodies continue to be used widely. In this issue of the Journal, seven groups of investigators report a lack of selectivity of a large number of receptor antibodies for the claimed target receptor. This includes antibodies against subtypes of $\alpha_{1}$-adrenoceptors (Jensen et al. 2009), $\beta$-adrenoceptors (Hamdani and van der Velden 2009; Pradidarcheep et al. 2009), dopamine receptors (Bodei et al. 2009), muscarinic receptors (Jositsch et al. 2009; Pradidarcheep et al. 2009), and galanin receptors (Lu and Bartfai 2009). An additional report shows similar problems with antibodies against receptors from the family of ligand-gated ion channels, specifically the TRPV1 receptors (Everaerts et al. 2009), although other antibodies directed against these receptors apparently are selective by hard criteria (Charrua et al. 2009). In total, 49 antisera against 19 distinct receptors have been tested in those studies, 10 of which were tested by more than one group of investigators; in many cases multiple antibodies were investigated per receptor. However, none of them was found to be selective. Taken together, these reports suggest that a lack of selectivity of GPCR and perhaps other receptor antibodies is the rule rather than the exception. In the following we will discuss why so many GPCR antibodies lack selectivity and what we consider to be reliable criteria to demonstrate the specificity of receptor antibodies.

\section{Why do so many GPCR antibodies lack selectivity?}

One possible explanation is that subtypes of a given GPCR typically have high degrees of homology and hence antibodies may easily recognize other subtypes within the same family. Indeed, one study reported here shows that antibodies against either $\beta_{2}$ - or $\beta_{3}$-adrenoceptors recognize rather similar band patterns on immunoblots from cells expressing any of the nine adrenoceptors subtypes (Pradidarcheep et al. 2009). However, the problem apparently goes well beyond the homology of closely related GPCR subtypes. For example, airways express only the $\mathrm{M}_{2}$ and $\mathrm{M}_{3}$ subtype of muscarinic receptors (Michel and Parra 2008) but double-knock-out mice lacking both subtypes still stained positive for $\mathrm{M}_{2}$ and $\mathrm{M}_{3}$ receptor antibodies (Jositsch et al. 2009). Similarly, triple knock-out mice lacking all three $\alpha_{1}$-adrenoceptor subtypes show similar staining patters as wild-type mice (Jensen et al. 2009). Thus, if lack of selectivity is due to structural similarity between GPCR, this may extend beyond members of a given family to the overall group. If that was true, antibodies raised against less conserved regions of GPCR, e.g. the $\mathrm{N}$ - or $\mathrm{C}$-terminal tails may have a better chance for selectivity. However, some findings in this issue of the Journal demonstrate that $\mathrm{N}$ - and C-terminal-directed antibodies similarly lack specificity as those directed against more conserved receptor domains (Jensen et al. 2009; Jositsch et al. 2009). Irrespective of such considerations, these problems suggest that many previously published data, including some in this Journal (Otsuka et al. 2008; van Diepen et al. 2008), may require re-interpretation. This shows that irrespective of a good explanation for the lack of selectivity of many GPCR antibodies, it is important to develop better criteria to accept an antibody as specific for its target.

\section{Criteria to demonstrate receptor antibody specificity}

The problems with many existing antibodies necessitate revisiting which criteria are acceptable to demonstrate selectivity of an antibody for its claimed cognate receptor. The criterion most often applied in the past is disappearance of staining in the presence of blocking peptide, i.e. the peptide against which the antiserum was raised. However, the examples in this issue of the Journal demonstrate that this is insufficient to demonstrate selectivity as almost all of the tested antibodies had been claimed to be selective based upon blocking peptide testing. A second soft criterion used in the past is that antibodies against different subtypes of a given receptor exhibit distinct staining patters in tissues. However, studies with both knock-out mice (Everaerts et al. 2009; Jensen et al. 2009; Jositsch et al. 2009; Lu and Bartfai 2009; Pradidarcheep et al. 2008) or immunoblots comparing staining to cloned receptor subtypes (Bodei et al. 2009; Hamdani and van der Velden 2009; Pradidarcheep et al. 2009) demonstrate that this also is insufficient to prove selectivity. Rather we propose that at least one of the following four conditions must be met to consider an antiserum to indeed be selective. 
Firstly, selectivity of an antibody is likely if its staining disappears in immunohistochemical studies or immunoblots of tissues from animals genetically engineered to lack that receptor. Several studies demonstrate that many available antibodies fail to meet this test (Everaerts et al. 2009; Jensen et al. 2009; Jositsch et al. 2009; Lu and Bartfai 2009; Pradidarcheep et al. 2008). Secondly, animals or cell lines can be treated with genetic tools to knock-down expression of a given receptor, e.g. siRNA; if that leads to a major reduction of staining by a given antibody, this also constitutes reasonable evidence for its specificity. Thirdly, studies with transfection of multiple subtypes of a given receptor into the same host cell line in which the target receptor but not the related subtypes yield positive staining also can provide strong evidence for selectivity (Bodei et al. 2009; Hamdani and van der Velden 2009; Pradidarcheep et al. 2009). Finally, in a more classical immunological approach, it can be considered as reasonable evidence of selectivity if multiple antibodies raised against different epitopes of a GPCR, e.g. N-terminus, intracellular loop and C-terminus, show a very similar staining pattern in immunohistochemistry and/or immunoblotting. Of note, with the possible exception of the third proposed option, all of these criteria may also be applied to antibodies raised against targets other than GPCR. A recent report demonstrates an additional approach based on tagged receptors, in which a GPCR antibody detects the same protein as the antibody against the tag (Miyauchi et al. 2009); however, this approach needs to be validated in further studies using the hard criteria described above.

\section{Additional considerations for the validation of receptor antibodies}

The apparent selectivity or lack thereof for a receptor antibody may also depend on other factors. For example, in immunohistochemical studies the recognition pattern of an antiserum may depend on the protocols used for tissue fixation (Jensen et al. 2009). Also, an antibody raised against a recombinant protein or part of it might be highly specific in immunohistochemistry, but is not able to detect the protein after its threedimensional structure has been destroyed, e.g. by solubilization in Laemmli buffer.

Selectivity data based upon immunoblots may be liable to additional problems when used for other purposes. Thus, even if a band of appropriate size is present only in extracts of cells expressing the target receptor but not in those expressing related subtypes, this does not necessarily demonstrate the usefulness of such antibodies for immunohistochemistry. As immunohistochemistry relies on the idea that all or at least most staining comes from the target protein, staining of additional bands in immunoblots may be a significant source of error when using the same antiserum in immunohistochemistry. Thus, the number of detected bands on an immunoblot may to a large degree depend protein loading of the gel, and only antibodies exhibiting immunoblot specificity over a wide range of loading densities may have sufficient specificity for immunohistochemistry. A variation of this idea is that an antibody may exhibit "specificity" when tested on cell lines with marked overexpression but not when much lower physiological expression densities are assessed, i.e. has poor sensitivity for its target receptor. This is particularly true if evidence for specificity is based solely on the presence of a band on immunoblots from overexpressing as compared to mock-transfected cells.

\section{Conclusions and future editorial policy}

As a lack of selectivity appears to be the rule rather than the exception with GPCR antibodies, the scientific community should consider which requirements are agreed upon to consider an antibody to have validated selectivity for its claimed cognate receptor. To initiate such discussion, we propose four criteria, of which at least one should be fulfilled as reasonable evidence for selectivity. At least for this Journal, this will become an editorial policy for all manuscripts which use GPCR antibodies. We additionally propose that similarly rigorous validation approaches should also be applied to antibodies against targets other than GPCR. Finally, the various reports in this issue of the journal imply that lack of selectivity of receptor antibodies is not a problem of one or two specific commercial suppliers but rather appears to be applicable to all antibody sources, both commercial and academic. As the data in this issue of the journal raise more questions than provide answers, the journal welcomes scientific comments from the academic community and commercial antibody suppliers with regard to strategies for improved antibody selectivity and/or criteria to demonstrate such selectivity.

Open Access This article is distributed under the terms of the Creative Commons Attribution Noncommercial License which permits any noncommercial use, distribution, and reproduction in any medium, provided the original author(s) and source are credited.

\section{References}

Bodei S, Arrighi N, Spano P, Sigala S (2009) Should we be cautious on the use of commercially available antibodies to dopamine receptors? Naunyn-Schmiedeberg's Arch Pharmacol. doi:10.1007/ s00210-008-0384-6 
Charrua A, Cruz CD, Narayanan S, Gharat L, Gullapali S, Cruz F, Avelino A (2009) GRC-6211, a new oral specific TRPV1 antagonist, decreases bladder overactivity and noxious bladder input in cystitis animal models. J Urol 181:379-386

Chen W, Mahadomrongkul V, Berger UV, Bassan M, DeSilva T, Tanaka K, Irwin N, Aoki C, Rosenberg PA (2004) The glutamate transporter GLT1a is expressed in excitatory axon terminals of mature hippocampal neurons. J Neurosci 24:1136-1148

Everaerts W, Sepulveda MR, Gevaert T, Roskams T, Nilius B, de Ridder D (2009) Where is TRPV1 expressed in the bladder, do we see the real channel? Naunyn-Schmiedeberg's Arch Pharmacol (in press)

Gupta A, Devi LA (2006) The use of receptor-specific antibodies to study G-protein-coupled receptors. Mt Sinai J Med 73:673-681

Hamdani N, van der Velden J (2009) Lack of specificity of antibodies directed against human beta-adrenergic receptors. NaunynSchmiedeberg's Arch Pharmacol. doi:10.1007/s00210-009-0392-1

Hawes JJ, Picciotto MR (2005) Corrigendum. J Comp Neurol 490:98-100

Herber DL, Severance EG, Cuevas J, Morgan D, Gordon MN (2004) Biochemical and histochemical evidence of nonspecific binding of $\alpha 7 \mathrm{nAChR}$ antibodies to mouse brain tissue. J Histochem Cytochem 52:1367-1375

Ibba M, Kitayama M, McDonald J, Calo G, Guerrini R, Farkas J, Toth G, Lambert DG (2008) Binding of the novel radioligand $\left[{ }^{3} \mathrm{H}\right]$ UFP-101 to recombinant human and native rat nociceptin/orphanin FQ receptors. Naunyn-Schmiedeberg's Arch Pharmacol 378:553-561

Insel PA, Tang C-M, Hahntow I, Michel MC (2007) Impact of GPCRs in clinical medicine: genetic variants and drug targets. Biochim Biophys Acta 1768:994-1005

Jensen BC, Swigart PM, Simpson PC (2009) Ten commercial antibodies for alpha-1-adrenergic receptor subtypes are nonspecific. Naunyn-Schmiedeberg's Arch Pharmacol (in press)

Jongsma M, Florczyk UM, Hendriks-Balk MC, Michel MC, Peters SLM, Alewijnse AE (2007) Validation of a rapid, nonradioactive method to quantify internalization of G-protein coupled receptors. Naunyn-Schmiedeberg's Arch Pharmacol 375:329-336

Jositsch G, Papadakis T, Haberberger RV, Wolff M, Wess J, Kummer W (2009) Suitability of muscarinic acetylcholine receptor antibodies for immunohistochemistry evaluated on tissue sections of receptor gene-deficient mice. Naunyn-Schmiedeberg's Arch Pharmacol. doi:10.1007/s00210-008-0365-9

Lu X, Bartfai T (2009) Analyzing the validity of GalR1 and GalR2 antibodies using knockout mice. Naunyn-Schmiedeberg's Arch Pharmacol. doi:10.1007/s00210-009-0394-Z

Mackrill JJ (2004) Generation, use, and validation of receptorselective antibodies. Methods Mol Biol 259:47-65
Michel MC, Parra S (2008) Similarities and differences in the autonomic control of airway and urinary bladder smooth muscle. Naunyn-Schmiedeberg's Arch Pharmacol 378:217-224

Miyauchi S, Hirasawa A, Iga T, Ning L, Itsubo C, Sadakane K, Hara T, Tsujimoto $G$ (2009) Distribution and regulation of protein expression of the free fatty acid receptor GPR120. NaunynSchmiedeberg's Arch Pharmacol. doi10.1007/s00210-008-0390-8

Myslivecek J, Duysen EG, Lockridge O (2007) Adaptation to excess acetylcholine by downregulation of adrenoceptors and muscarinic receptors in lungs of acetylcholinesterase knockout mice. NaunynSchmiedeberg's Arch Pharmacol 376:83-92

Myslivecek J, Klein M, Novakova M, Ricny J (2008) The detection of the non- $\mathrm{M}_{2}$ muscarinic receptor subtype in the rat heart atria and ventricles. Naunyn-Schmiedeberg's Arch Pharmacol 378:103-116

O'Connell TD, Swigart PM, Rodrigo MC, Ishizaka S, Joho S, Turnbull L, Tecott LH, Baker AJ, Foster E, Grossman W, Simpson PC (2006) $\alpha_{1}$-Adrenergic receptors prevent a maladaptive cardiac response to pressure overload. J Clin Invest 116:1005-1015

Otsuka A, Shinbo H, Matsumoto R, Kurita Y, Ozono S (2008) Expression and functional role of $\beta$-adrenoceptors in the human urinary bladder. Naunyn-Schmiedeberg's Arch Pharmacol 377:473-481

Penn RB (2008) Embracing emerging paradigms of G protein-coupled receptor agonism and signaling to address airway smooth muscle pathobiology in asthma. Naunyn-Schmiedeberg's Arch Pharmacol 378:149-169

Pradidarcheep W, Labruyere WT, Dabhoiwala NF, Lamers WH (2008) Lack of specificity of commercially available antisera: Better specifications needed. J Histochem Cytochem 56:1099-1111

Pradidarcheep W, Stallen J, Labruyere WT, Dabhoiwala NF, Michel MC, Lamers WH (2009) Lack of specificity of commercially available antisera against muscarinic and adrenergic receptors. NaunynSchmiedeberg's Arch Pharmacol. doi10.1007/s00210-009-0393-0

Rhodes KJ, Trimmer JS (2006) Antibodies as valuable neuroscience research tools versus reagents of mass distraction. J Neurosci 26:8017-8020

Tanaka T, Yano T, Adachi T, Koshimizu T, Hirasawa A, Tsujimoto G (2008) Cloning and characterization of the rat free fatty acid receptor GPR120: In vivo effect of the natural ligand on GLP-1 secretion and proliferation of pancreatic $\beta$ cells. NaunynSchmiedeberg's Arch Pharmacol 377:515-522

van Diepen H, Schlicker E, Michel MC (2008) Prejunctional and peripheral effects of the cannabinoid $\mathrm{CB}_{1}$ receptor inverse agonist rimonabant (SR141716). Naunyn-Schmiedeberg's Arch Pharmacol 378:345-369

Vrydag W, Michel MC (2007) Tools to study $\beta_{3}$-adrenoceptors. Naunyn-Schmiedeberg's Arch Pharmacol 374:385-398 